\title{
Myeloid Leukemia Factor 1
}

National Cancer Institute

\section{Source}

National Cancer Institute. Myeloid Leukemia Factor 1. NCI Thesaurus. Code C97652.

Myeloid leukemia factor 1 (268 aa, $\sim 31 \mathrm{kDa}$ ) is encoded by the human MLF1 gene. This protein plays a role in both the modulation of transcription and cell cycle regulation. 